\title{
Should MRI replace mammography as the initial screening modality for asymptomatic women aged $18-45$ years at high risk of developing breast cancer? A systematic review
}

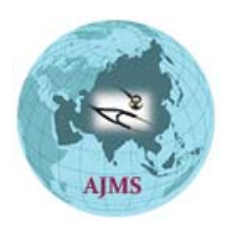

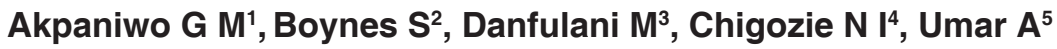 \\ ${ }_{1,5}^{1,5}$ Assistant Lecturer, ${ }^{2,4}$ Senior Lecturer, Department of Radiography, Faculty of Health Sciences, University of \\ Bradford, Bradford, England, ${ }^{3}$ Consultant Radiologist, Department of Radiology, Usmanu Danfodiyo University Sokoto, \\ Sokoto State, Nigeria
}

\section{A B S T R A C T}

Background: Breast cancer occurs in both men and women, although it is more prevalent among women. Mammography is generally the diagnostic imaging modality of choice, but it is limited in the detection of breast cancer in young women, aged 18-45 years due to the dense nature of their breast tissue. Aims and Objectives: This review explores whether MRI should replace mammography as the initial screening modality for asymptomatic women, aged 18-45 years at high risk of developing breast cancer. Materials and Methods: A systematic review of the literature was undertaken. A search of Medline, Pubmed central, Cinahl and Google scholar for English language literature from 2004 to 2015 was undertaken. Also a review of reference lists, author searching and review of NICE evidence base for exiting guidelines was done. Included studies were assessed for bias using STARD quality assessment tool and data were extracted systematically using a purposefully designed data extraction form. Result: From the seven included studies, 179 participants of the total population had breast cancer and a total of 199 breast cancer was detected by both modality used. MRI detected a total 148 breast cancers compared to 78 detected by mammography, and 10 interval cancer was reported. Sensitivity estimate from the included studies ranged from $25 \%$ to $100 \%$ while specificity ranged from $79 \%$ to $99 \%$. MRI detected more breast cancer but had a moderate specificity compared to mammography as reported in the literature. Conclusion: In the absence of contraindication and accessibility, MRI should be used as the initial screening modality for asymptomatic women aged $18-45$ years, at high risk of developing breast cancer.

Key words: Asymptomatic, Breast cancer, BRCA1, BRCA2, MRI, Mammography

\section{INTRODUCTION}

Breast cancer in asymptomatic women aged 18 to 45 years who are predisposed to the gene mutation (Breast cancer 1(BRCA1) and Breast cancer 2 (BRCA2)) or with a strong family history of breast cancer are often given less attention. ${ }^{1}$ In 2012, out of the 14.1 million new cases of cancer diagnosed in the world, 1.7 million were due to breast cancer in women, which represent an incidence rate of $25 \%$ of all cancers in women. ${ }^{2}$ It is however noted that breast cancer susceptibility gene (BRCA1 and BRCA2) may be responsible for $5-10 \%$ of all breast cancer cases in the general population. ${ }^{3}$ And the carriers of this susceptibility gene, faces a lifetime risk of $60 \%$ to $80 \%$ of developing the disease. ${ }^{4,5}$

In asymptomatic women aged 18 to 45 years at high risk of developing breast cancer, mutational test is 
usually recommended for them. The test is performed by mutation screening to identify the gene (BRCA1 and BRCA2). The mutational screening processes involve a combination of proteins-truncation test and heteroduplex analysis, supplemented with linkage analysis of BRCA1 and BRCA2 alleles. ${ }^{6}$ BRCA1 and BRCA2 mutation accounts for $20 \%$ to $25 \%$ of hereditary breast cancer ${ }^{7}$ and in young asymptomatic women aged 18 to 45 years at high risk, BRCA1 and BRCA2 are held responsible for the development of the breast cancer and often both breasts are affected by the disease. ${ }^{8}$ Breast cancer at advanced stage in asymptomatic women aged 18 to 45 years are usually of the aggressive subtype with adverse pathological factors, which may include high grade tumours, lymphovascular invasion, hormone receptor negativity, and HER2 overexpression. ${ }^{9,10}$ These are usually classified as HER2-positive breast cancer (those that test positive to the protein - Human Epidermal growth factor Receptor 2 (HER2)). It becomes imperative to detect this cancer at an early age in these women and also in older women for effective management of the disease. Over the years Mammography has been used in the screening of breast cancer and in the reduction of breast cancer mortality in postmenopausal women by about $20 \%$ to $35 \%{ }^{11}$ It was reported to have a sensitivity of about $36 \%-46 \%$ and specificity of $93 \%-99.8 \% .{ }^{12-16}$ But has a known limitation in the detection of breast cancer in younger women aged 18 to 45 years, due to the dense nature of their breast tissues, leading to increased mammographic densities which obscure radiologic features of early breast cancer. ${ }^{17}$ More so germ line mutation gene (BRCA1 and BRCA2) which are associated with breast cancer in young high risk women have benign appearance on mammography, especially BRCA $1 .{ }^{17}$ In this group of women, mammography is reported to have a sensitivity of about $25 \%$ and specificity of $96.8 \% .{ }^{15}$ However, approximately $6.6 \%$ of all breast cancer cases are diagnosed in women younger than 40 years, while $2.4 \%$ of these are diagnosed in women less than 35 years and $0.65 \%$ in women less than 30 years. ${ }^{10}$

The impact of this limitation was reduced by the introduction of adjunct screening modalities such as highfrequency breast Ultrasound, Clinical breast examination (CBE), and Magnetic resonance imaging (MRI). Currently, annual clinical breast examination, Surgery, Radiation therapy and mammography (beginning at age 40), are used in the management of women at high risk of developing breast cancer.

This review is set to explore whether Magnetic Resonance Imaging (MRI) should replace mammography as the initial screening modality for asymptomatic women, aged 18-45 years at high risk of developing breast cancer.

\section{MATERIALS AND METHODS}

A search of Medline, PubMed Central (PMC), and Cinahl databases and Google scholar was undertaken supplemented by hand searching of some imaging journals (Synergy and British journal of Radiology; Radiography), review of the National Institute for Health \& Care Excellence (NICE) evidence base for existing guidelines. Also review of reference lists, author searching was undertaken. Citations were identified using the Medical Subject Heading terms $(\mathrm{MeSH})$ and key search terms and their alternatives: Breast cancer (Asymptomatic; BRCA1; BRCA2), Magnetic Resonance Imaging (MRI; MR; Nuclear Magnetic Resonance (NMR)); Mammography (Mammo). The search was limited to primary research studies published in English from 2004 to July 2015, in order to take advantage of recent technological advancement in MRI. After the identification of potential relevant research studies, the title, abstracts and when necessary the full text of the yielded search result, were screened to determine whether they met the inclusion/exclusion, which was derived from the primary research question "Should MRI replace mammography as the initial screening modality for asymptomatic women aged 18-45 years at high risk of developing breast cancer?" and are listed in Table 1. The rule out principle was employed in the selection of included primary research papers and where the reviewer was certain that a paper lack the necessary information, they were rejected. However at each stage where the reviewer was uncertain, whether a paper should be included, the paper was retained. All retained paper was re-examined to make final decision on inclusion/exclusion.

The included papers were assessed for quality using the Standards for Reporting of Diagnostic Accuracy (STARD), ${ }^{18,26}$ by at least 2 authors and data were extracted into Microsoft $\mathrm{Excel}^{27}$ spread sheet for consistency using a purposefully designed data extraction form. However paper's with uncertainty in quality was resolved through discussion and consensus was reached. The STARD ${ }^{26}$ assessment checklist was used to document the paper quality (Table 2). Each article were then rated to determine the overall quality, using Good, Fair or Poor rating scale. From the summary, each study had a Yes $(\mathrm{Y})$ to No $(\mathrm{N})$ score of $19 / 25,23 / 25,24 / 25,19 / 25,22 / 25+1$ unclear, $21 / 25,19 / 25+2$ unclear, respectively. Four studies had an overall quality rating of 'Good' and three had a 'Fair' overall rating. This implies that a thorough methodology was used and common bias of diagnostic accuracy studies was low. However none of the included studies was ratted poor. A final value of award was given to each paper, where 'High' was given to a study with low risk of bias, 'Average' was given to studies with an unclear risk of bias and 'low' 


\begin{tabular}{|c|c|c|}
\hline Question component & Inclusion criteria & Exclusion criteria \\
\hline Population & $\begin{array}{l}\text { - Asymptomatic women } 18-45 \text { years at } \\
\text { high risk of developing breast cancer }\end{array}$ & $\begin{array}{l}\text { - Studies involving symptomatic women and studies involving } \\
\text { young women where data could not be clearly evaluated }\end{array}$ \\
\hline Index test & - MRI & $\begin{array}{l}\text { - Studies not involving MRI or where MRI data cannot be } \\
\text { evaluated independently }\end{array}$ \\
\hline Comparator test & - Mammography & - Other imaging modality \\
\hline Outcome measures & $\begin{array}{l}\text { - Sensitivity and Specificity } \\
\text { - Diagnostic accuracy } \\
\text { - Type of cancer detected. }\end{array}$ & $\cdot-$ \\
\hline Study design & - Prospective studies & $\begin{array}{l}\text { - Studies without comparison between Mammography and MRI } \\
\text { - Retrospective studies }\end{array}$ \\
\hline Reference Standard & $\begin{array}{l}\text { - Histopathology } \\
\text { - Biopsy }\end{array}$ & $\cdot-$ \\
\hline
\end{tabular}

was given to studies with a high risk of bias in the final evaluation (Table 3).

The data extracted was compared and data analysis was done by descriptive synthesis. ${ }^{24}$ A Meta-analysis was inappropriate due to the variations in the extracted data, technical parameters, methods of determining diagnostic accuracy and clinical characteristic.

\section{RESULTS}

Figure 1 shows a flow chart diagram, detailing the review process. The detail of the included studies and quality assessment awarded are summarized in Table 3. Tables 4 and 5 holds the details of the index test characteristics and extracted outcome measures.

\section{Sensitivity estimates}

All the included studies, used biopsy and positive test (Histopathology) as the reference standard. Sensitivity across the included studies ranged from $71 \%$ to $100 \%$. In two studies (Leach et al. ${ }^{14}(2005)$ and Hagen et al. ${ }^{19}(2007)$ ), different volume of Gadolinium contrast was administered. Leach et al. ${ }^{14}$ (2005) administered intravenously $0.1 \mathrm{mmol} / \mathrm{kg}$ and $0.2 \mathrm{mmol} / \mathrm{kg}$ bodyweight while Hagen et al. ${ }^{19}$ (2007) administered intravenously $0.1 \mathrm{mmol} / \mathrm{kg}$ and $20 \mathrm{ml}$. They reported a sensitivity of $77 \%$ and $86 \%$ respectively, which was lower than that reported by Lehman et al. ${ }^{22}$ (2005) and Kuhl et al. ${ }^{15}$ (2005) who administered consistently $0.1 \mathrm{mmol} / \mathrm{kg}$ bodyweight.

\section{Specificity estimates}

Specificity across the included studies ranged from $79 \%$ to $97 \%$. The study by (Leach et al. ${ }^{14}$ (2005)) reported a specificity of $81 \%$ but there was no record of specificity reported by Hagen et al. ${ }^{19}$ (2007). The study by Weinstein et al. ${ }^{21}$ (2009) reported the lowest specificity at $79 \%$ with all other studies reporting a sensitivity of $90 \%$ and higher.

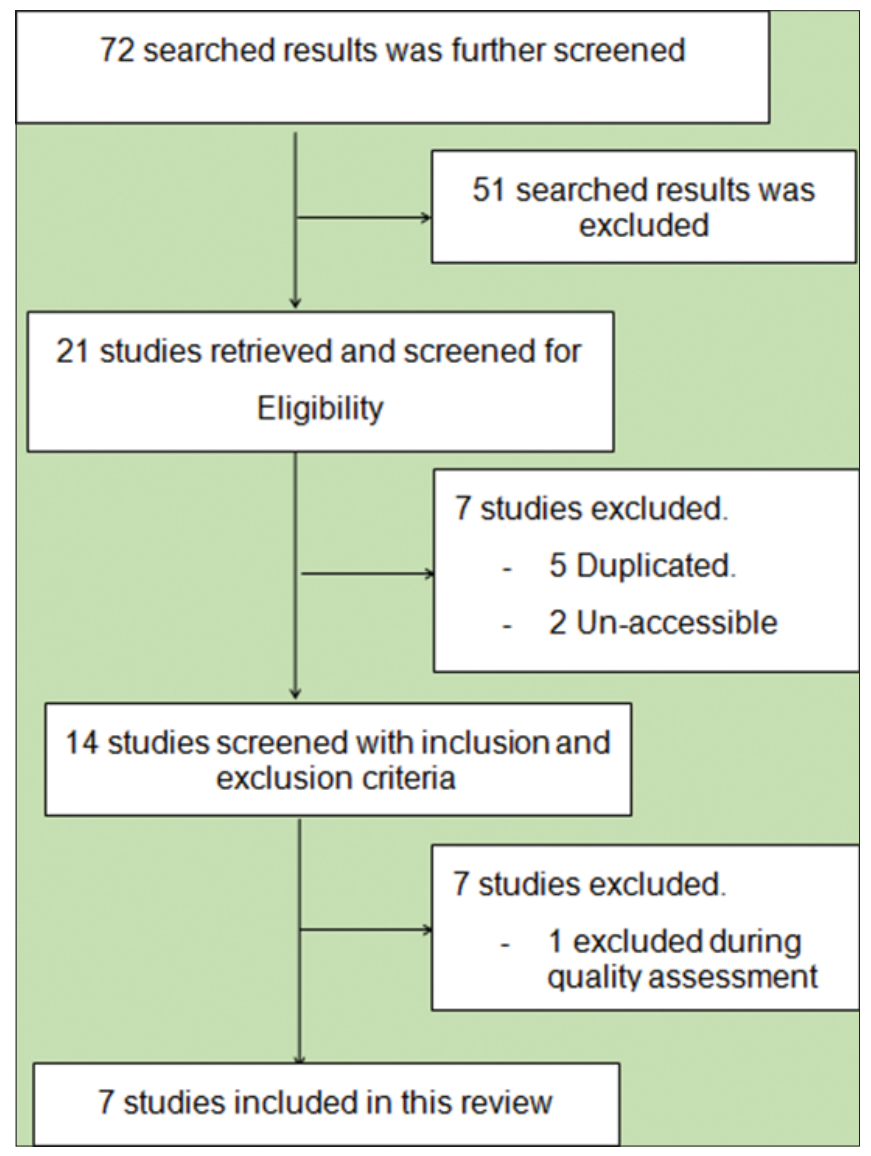

Figure 1: Flow diagram outline the screening process

Variations in diagnostic pulse sequence, scan time, and slice thickness

There was a significant variation in the scan time among the included studies, which depends on the magnetic field strength, pulse sequence used and RF coil type. Three studies, Weinstein et al., Leach et al., and Hagen et al., used a dedicated breast coil, while three other studies did not report the coil type used (Lehman et al., Kriege et al., and Kuhl et al.,). Only one study by Warner et al. made used of a phase array coil. All study employed the use of $1.5 \mathrm{~T}$ magnet, which is the most common magnet field strength in the UK. However Weinstein et al. and Leach et al. also 


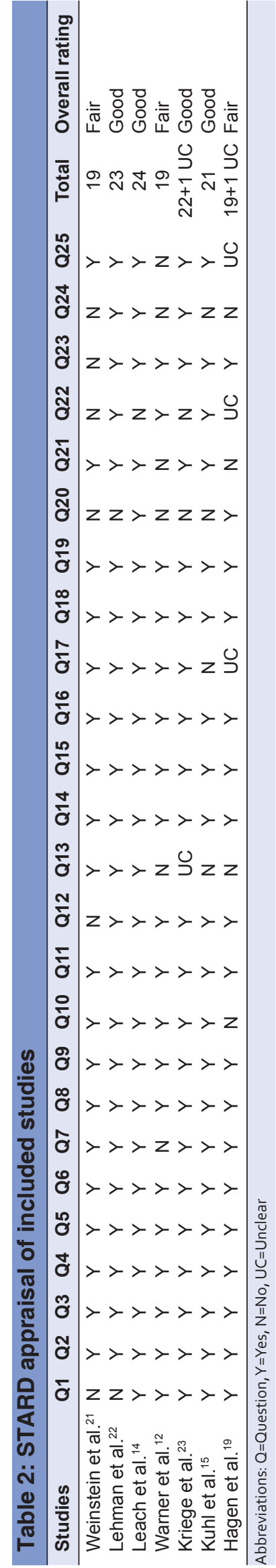

combined a 3T and 1T magnet in their study. There was no report of the magnetic field strength used by Lehman et al., and Kriege et al. With regard to the pulse sequence used, there is a significant variation between the studies. Three studies, Weinstein et al., Lehman et al., and Warner et al. included T2 sequences. Only the study of Leach et al. included a T1 sequence. Spoiled Gradient Recalled Acquisition in Steady State (SPGR) was employed in one study (Warner et al.) and a Dynamic contrast enhanced 3D (DCE 3D) was employed by Hagen et al., Fat saturation was used by all studies except Hagen et al. and two other studies that did not give a report of the sequence used (Kriege et al., and Kuhl et al.)

Scan time depend largely on the MRI field strength and sequence used, as a result of this, there were variation in the scan time among the included studies. Three studies (Weinstein et al., Warner et al., Hagen et al.) recorded a scan time less than $1.50 \mathrm{sec}$ per sequence. However, Weinstein et al. recorded $6 \mathrm{~min}$ in the post contrast series, and Hagen et al. reported a record of $7 \mathrm{~min}$. There was no record from four studies (Lehman et al., Leach et al., Kriege et al., and Kuhl et al.)

\section{Diagnostic accuracy analysis}

A total of 199 cancer was diagnosed, of which 148 was detected by MRI and 78 by Mammography. Among this detected cancers, it was observed that some type of cancers was detected more on one modality than on the other, this is summarise in Table 5. Three studies reported 10 interval cancer, ${ }^{12,13,19}$ while four studies did not. ${ }^{14,15,20,21}$ Mammography had the lowest sensitivity between 25\% to $50 \%$ and a high specificity between $93 \%$ and $99 \%$, while MRI had the highest sensitivity between $71 \%$ to $100 \%$ and a low specificity of $79 \%$ to $97 \%$. The diagnostic yields are summarized in Table 6. Similarly, a plot of sensitivity and specificity for each modality is graphically demonstrated on Figure 2. It was observed that the sensitivity of all the included studies for MRI, showed a slight difference in the sensitivity values, while that for Mammography shows a cluster of similar sensitivity values when plotted against specificity. From the graph, the area of the circle illustrate the sample size, a larger circle area represents a larger sample size. The results consistently show's that the specificities of MRI and mammography are similar but that the sensitivity of mammography is consistently lower than that of MRI.

\section{DISCUSSION}

In these review, from the seven included studies, a pool of 4,793 asymptomatic women at high-risk of developing breast cancer were screened, most of whom were BRCA1 


\begin{tabular}{|c|c|c|c|c|c|c|c|c|c|}
\hline $\begin{array}{l}\text { Study author/ } \\
\text { year }\end{array}$ & Title & Objective & Location & Study type & $\begin{array}{l}\text { No. of } \\
\text { patient } \\
\text { (n) }\end{array}$ & $\begin{array}{l}\text { Number of } \\
\text { withdrawal/ } \\
\text { exclusion }\end{array}$ & $\begin{array}{l}\text { Mean } \\
\text { age }\end{array}$ & Ethnicity & QA \\
\hline $\begin{array}{l}\text { Weinstein } \\
\text { et al. }{ }^{21}(2009)\end{array}$ & $\begin{array}{l}\text { Multimodality screening } \\
\text { of high-risk women: } \\
\text { A prospective cohort2 } \\
\text { study }\end{array}$ & $\begin{array}{l}\text { To prospectively } \\
\text { compare cancer } \\
\text { detection of digital } \\
\text { mammography, } \\
\text { whole-breast } \\
\text { ultrasound and } \\
\text { contrast-enhanced } \\
\text { MRI in a high-risk } \\
\text { screening population } \\
\text { previously screened } \\
\text { negative by film } \\
\text { screen mammogram }\end{array}$ & Philadelphia & Prospective & 612 & 3 & 49 years & - & Average \\
\hline $\begin{array}{l}\text { Lehman } \\
\text { et al. }{ }^{22}(2005)\end{array}$ & $\begin{array}{l}\text { Screening women } \\
\text { at high risk for } \\
\text { breast cancer with } \\
\text { mammography and } \\
\text { magnetic resonance } \\
\text { imaging }\end{array}$ & $\begin{array}{l}\text { To determine } \\
\text { the feasibility } \\
\text { of using MRI to } \\
\text { screen high risk } \\
\text { patients for breast } \\
\text { cancer, including } \\
\text { determining whether } \\
\text { imaging and biopsy } \\
\text { procedures are } \\
\text { reliableand ensuring } \\
\text { that the proposed } \\
\text { interpretation } \\
\text { criteria do not } \\
\text { result in excessive } \\
\text { false-positive } \\
\text { examination }\end{array}$ & $\begin{array}{l}\text { United } \\
\text { States and } \\
\text { Canada }\end{array}$ & Prospective & 367 & 23 & 45 years & - & Average \\
\hline $\begin{array}{l}\text { Leach et al. }{ }^{14} \\
(2005)\end{array}$ & $\begin{array}{l}\text { Screening with Magnetic } \\
\text { resonance imaging and } \\
\text { mammography of a } \\
\text { UK population at high } \\
\text { familial risk of breast } \\
\text { cancer: a prospective } \\
\text { cohort study }\end{array}$ & $\begin{array}{l}\text { To compare the } \\
\text { diagnostic accuracy } \\
\text { of yearly contrast } \\
\text { enhanced MRI with } \\
\text { X-ray mammography } \\
\text { in women aged } \\
35-49 \text { years }\end{array}$ & $\begin{array}{l}\text { United } \\
\text { Kingdom }\end{array}$ & Prospective & 649 & 189 & 40 years & - & Average \\
\hline $\begin{array}{l}\text { Warner et al. }{ }^{12} \\
(2004)\end{array}$ & $\begin{array}{l}\text { Surveillance of } \\
\text { BRCA1 and BRCA2 } \\
\text { mutation carriers with } \\
\text { magnetic resonance } \\
\text { imaging, ultrasound, } \\
\text { mammography, } \\
\text { and clinical breast } \\
\text { examination }\end{array}$ & $\begin{array}{l}\text { To compare the } \\
\text { sensitivity and } \\
\text { specificity of } \\
4 \text { methods of breast } \\
\text { cancer surveillance } \\
\text { (Mammography, } \\
\text { ultrasound, } \\
\text { MRI, CBE) in } \\
\text { women hereditary } \\
\text { susceptibility to } \\
\text { breast cancer due to } \\
\text { a BRCA1 or BRCA2 } \\
\text { mutation }\end{array}$ & Canada & Prospective & 236 & 62 & 47 years & $\begin{array}{l}\text { Ashkenazi } \\
\text { Jewish }\end{array}$ & Average \\
\hline $\begin{array}{l}\text { Kriege et al. }{ }^{23} \\
(2004)\end{array}$ & $\begin{array}{l}\text { Efficacy of MRI and } \\
\text { mammography for } \\
\text { breast-cancer screening } \\
\text { in women with a familial } \\
\text { or genetic predisposition }\end{array}$ & $\begin{array}{l}\text { To determine } \\
\text { whether screening } \\
\text { with MRI facilitated } \\
\text { the early diagnosis } \\
\text { of hereditary cancer }\end{array}$ & Netherlands & Prospective & 1909 & 43 & 40 years & Dutch & Low \\
\hline $\begin{array}{l}\text { Kuhl et al. }{ }^{15} \\
(2005)\end{array}$ & $\begin{array}{l}\text { Mammography, breast } \\
\text { ultrasound, and } \\
\text { magnetic resonance } \\
\text { imaging for surveillance } \\
\text { of women at high } \\
\text { familial risk for breast } \\
\text { cancer }\end{array}$ & $\begin{array}{l}\text { To compare } \\
\text { individually the } \\
\text { respective diagnostic } \\
\text { accuracies achieved } \\
\text { with mammography, } \\
\text { breast ultrasound } \\
\text { and MRI }\end{array}$ & Germany & Prospective & 529 & 61 & 42 years & Germans & Average \\
\hline
\end{tabular}




\begin{tabular}{|c|c|c|c|c|c|c|c|c|c|}
\hline $\begin{array}{l}\text { Study authorl } \\
\text { year }\end{array}$ & Title & Objective & Location & Study type & $\begin{array}{l}\text { No. of } \\
\text { patient } \\
\text { (n) }\end{array}$ & $\begin{array}{l}\text { Number of } \\
\text { withdrawal/ } \\
\text { exclusion }\end{array}$ & $\begin{array}{c}\text { Mean } \\
\text { age }\end{array}$ & Ethnicity & QA \\
\hline $\begin{array}{l}\text { Hagen et al. }{ }^{19} \\
(2007)\end{array}$ & $\begin{array}{l}\text { Sensitivity of MRI } \\
\text { versus conventional } \\
\text { screening in } \\
\text { the diagnosis of } \\
\text { BRCA-associated } \\
\text { breast cancer in a } \\
\text { national prospective } \\
\text { series }\end{array}$ & $\begin{array}{l}\text { To compare the } \\
\text { sensitivities of breast } \\
\text { MRI and X-ray } \\
\text { mammography in the } \\
\text { diagnosis of cancer }\end{array}$ & Norway & Prospective & 491 & 63 & 41 years & Norwegian & Average \\
\hline
\end{tabular}

\begin{tabular}{|c|c|c|c|c|c|c|c|}
\hline Studies & $\begin{array}{l}\text { Field } \\
\text { strength }\end{array}$ & Pulse sequence & Parameter & Scan time & $\begin{array}{c}\text { Slice } \\
\text { thickness }\end{array}$ & Coil type & $\begin{array}{l}\text { Gadolinium agent per } \\
\text { bodyweight }\end{array}$ \\
\hline $\begin{array}{l}\text { Weinstein } \\
\text { et al..21 } \\
(2009)\end{array}$ & $\begin{array}{l}1.5 \mathrm{~T} \text { or } \\
3 \mathrm{~T}\end{array}$ & $\begin{array}{l}\text { Pre-contrast: } \\
\text { FAT-SAT T2 Sagittal. } \\
\text { Post-contrast: } \\
\text { FAT-SAT GE Sagittal }\end{array}$ & $\begin{array}{l}\text { TR/TE - }(4000 / 85) \\
\text { Matrix size }-512 \times 256 \\
\text { Slab Interleaved - } 13\end{array}$ & $\begin{array}{l}1 \mathrm{Min} \\
6 \mathrm{Min}\end{array}$ & $2-3.5 \mathrm{~mm}$ & $\begin{array}{l}\text { Dedicated } \\
\text { surface } \\
\text { breast } \\
\text { coil array }\end{array}$ & $\begin{array}{l}0.1 \mathrm{mmol} / \mathrm{kg} \\
\text { (Ominiscan) }\end{array}$ \\
\hline $\begin{array}{l}\text { Lehman } \\
\text { et al.22 } \\
\text { (2005) }\end{array}$ & $\begin{array}{l}\text { No } \\
\text { record }\end{array}$ & $\begin{array}{l}\text { Pre-contrast: } \\
\text { FSE T1, T2 Sagittal. } \\
\text { FAT-SAT T2 Sagittal. } \\
\text { Post-contrast: } \\
\text { FAT-SAT GE Sagittal }\end{array}$ & $\begin{array}{l}\text { Pre-contrast: } \\
\text { TR/TE }-(4000 / 80) \\
\text { Matrix size }-256 \times 256 \text {. } \\
\text { Sat T1 }(\text { TR } \leq 50 / T E \leq 4.5) \\
\text { Post-contrast: } \\
\text { Sat T1 }(T R \leq 50 / T E \leq 4.5) \\
\text { Matrix size }- \\
256 \times 128 \times 32-60 \text { (3D) } \\
\text { Flip angle }-60^{\circ} \\
\text { (Gradient echo) }\end{array}$ & No record & $\leq 3 \mathrm{~mm}$ & No record & No record \\
\hline $\begin{array}{l}\text { Leach } \\
\text { et al. } .^{14} \\
(2005)\end{array}$ & $\begin{array}{l}1.0 \mathrm{~T} \\
1.5 \mathrm{~T}\end{array}$ & FAT-SAT TI Coronal & & No record & No record & $\begin{array}{l}\text { Dedicated } \\
\text { breast } \\
\text { coil }\end{array}$ & $\begin{array}{l}0.1 \mathrm{mmol} \text { per } \mathrm{kg} . \\
0.2 \mathrm{mmol} \text { per } \mathrm{kg} \text {. } \\
\text { (Gadopentetatedimeglumine) }\end{array}$ \\
\hline $\begin{array}{l}\text { Warner } \\
\text { et al. }{ }^{12} \\
(2004)\end{array}$ & $1.5 \mathrm{~T}$ & $\begin{array}{l}\text { SPGR - Coronal. } \\
\text { SPGR - Sagittal, } \\
\text { FAT-SAT T2 - Sagittal } \\
\text { FSE T2 - Sagittal }\end{array}$ & $\begin{array}{l}\text { TR/TE }-12.9 \mathrm{~ms} / 43 \mathrm{~ms} \\
\mathrm{matrix}=256 \times 256 . \\
\text { TR/TE }-18.4 \mathrm{~ms} / 4.3 \mathrm{~ms} \\
\text { Flip angle }-40^{\circ} \\
\text { TR/TE }-4000 \mathrm{~ms} / 102 \mathrm{~ms} \\
\text { Flip angle }-40\end{array}$ & $1 \mathrm{~min} 30 \mathrm{~s}$ & $4-5 \mathrm{~mm}$ & $\begin{array}{l}\text { Phase } \\
\text { array coil }\end{array}$ & $\begin{array}{l}0.1 \mathrm{mmol} / \mathrm{kg} \\
\text { (Ominiscan) }\end{array}$ \\
\hline $\begin{array}{l}\text { Kriege } \\
\text { et al..23 } \\
(2004)\end{array}$ & $\begin{array}{l}\text { No } \\
\text { record }\end{array}$ & No record & No record & No record & No record & No record & No record \\
\hline $\begin{array}{l}\text { Kuhl } \\
\text { et al. } \\
\text { (2005) }\end{array}$ & $1.5 \mathrm{~T}$ & No record & No record & No record & No record & No record & $0.1 \mathrm{mmol} / \mathrm{kg}$ \\
\hline $\begin{array}{l}\text { Hagen } \\
\text { et al. } .^{19} \\
(2007)\end{array}$ & $1.5 \mathrm{~T}$ & $\begin{array}{l}\text { DCE 3D - T1 } \\
\text { Coronal. } \\
\text { DCE 3D - T1 } \\
\text { Coronal }\end{array}$ & No record & $\begin{array}{l}1.01-1.30 \mathrm{~min} . \\
7 \mathrm{~min}\end{array}$ & $\begin{array}{l}2.5-2.67 \mathrm{~mm} \\
2 \mathrm{~mm}\end{array}$ & $\begin{array}{l}\text { Dedicated } \\
\text { breast } \\
\text { coil }\end{array}$ & $\begin{array}{l}0.1 \mathrm{mmol} / \mathrm{kg} \\
20 \mathrm{ml}\end{array}$ \\
\hline
\end{tabular}

and BRCA2 mutation carrier and women with a strong family history of breast cancer. Of which 199 breast cancers was detected in 179 participants. A total of 444 participants were either withdrawn or excluded from the studies.

A high sensitivity of $71 \%$ to $100 \%$ and a low specificity of $79 \%$ to $97 \%$ were reported for MRI, and a low sensitivity of $25 \%$ to $50 \%$ and a high specificity of $93 \%$ and $99 \%$ were also reported for Mammography. MRI was found in all the included studies to be more sensitive in the screening of asymptomatic women (18-45 years) at high-risk of developing breast cancer compare to Mammography. The highest sensitivity in this review for MRI was reported by Lehman et al. ${ }^{22}$ with a sensitivity of $100 \%$ and the lowest was reported by Weinstein et al. ${ }^{21}$ with a sensitivity of $71 \%$. Hagen et al. ${ }^{19}$ reported the highest sensitivity for Mammography to be $50 \%$ and Lehman et al. ${ }^{22}$ reported the lowest with a sensitivity of $25 \%$. The huge difference in the sensitivity between MRI and mammography reported could be as a result of the comparative nature or biological factor of the breast of the screened population (18-45 years) in 
the study, since the sensitivity of mammography is inversely related to the density of the breast.

However, comparing the specificity of the two modalities, mammography was found to have a high specificity than MRI in five of the included studies with the highest specificity of $99.9 \%,{ }^{12}$ and the lowest with $93 \%,{ }^{14}$ while that reported for MRI was $97 \%{ }^{15}$ and $79 \% .{ }^{21}$ From this finding, there is only a slight difference in the specificity between both modality, which may be statistically significant in clinical practice.

However the true negative for MRI compared to Mammography was also slightly lower with a difference of 8 (Table 7), this slight difference could be attributed to the fact that only two studies ${ }^{12,15}$ actually gave a report for true negative (TN) values.

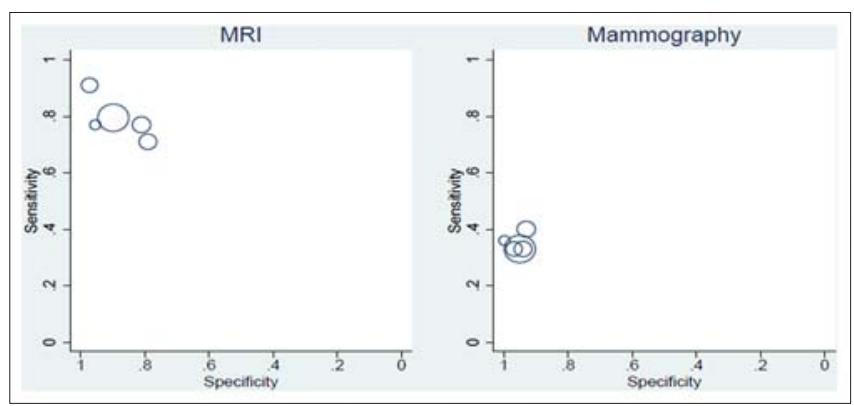

Figure 2: A graph of sensitivity and specificity for MRI and Mammography of the included studies
Similarly, false positive (FP) outcome was found to be higher screening with MRI than with Mammography (Table 7), which lead to increase number of participant who were sent for biopsy, compared to those sent from Mammography. The biopsy recommendation rate for MRI in three studies report ${ }^{15,21,22}$ was $25 \%, 8.5 \%, 78 \%$ and for Mammography, $29 \%, 2.2 \%, 59 \%$ respectively. Four of the other included studies did not give values for the biopsy recommendation rates for both modalities. This indicate that the biopsy recommendation rate was higher in MRI, exception of the $29 \%$ reported by Weinstein et al. ${ }^{21}$ for mammography, which was higher than the $25 \%$ reported for MRI.

The positive predictive values (PPV) for both of the modality also shows some significant difference, two of the included studies ${ }^{15,22}$ reported higher PPV for MRI $(12.9 \%, 50 \%)$ than Mammography $(12.5 \%, 23.7 \%)$ respectively. While in two other studies, ${ }^{12,14}$ Mammography had a higher PPV than MRI, $(10 \%, 80 \%$ Vs $7.3 \%, 42 \%)$ respectively. There was no report on PPV in the other three studies. ${ }^{19,21,23}$

A total of 111 Invasive cancer (IC) (56\% of total cancer detected) and 40 Ductal carcinoma in situ (DCIS) (20\% of total cancer detected) was detected in the course of the screening among the seven studies. It was observed from most of the included studies that Mammography was better

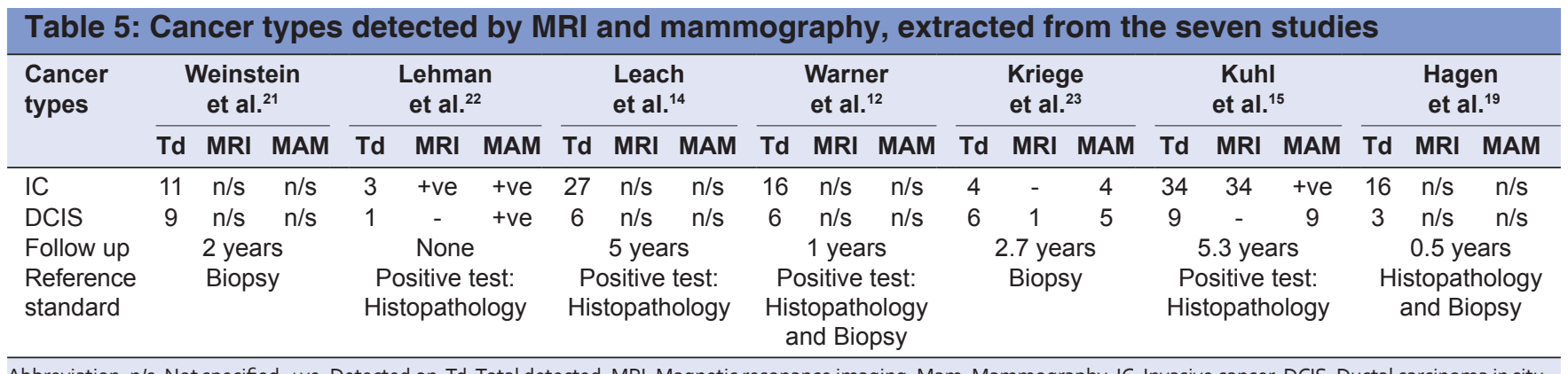

\begin{tabular}{|c|c|c|c|c|c|c|c|c|c|c|c|c|c|c|c|}
\hline \multirow[t]{2}{*}{$\mathbf{S} / \mathbf{N}$} & \multirow[t]{2}{*}{ Studies } & \multirow{2}{*}{$\begin{array}{l}\text { Study } \\
\text { design }\end{array}$} & \multirow{2}{*}{$\begin{array}{c}\text { No. of } \\
\text { participant }\end{array}$} & \multicolumn{3}{|c|}{$\begin{array}{c}\text { Cancer } \\
\text { yield }\end{array}$} & \multirow{2}{*}{$\begin{array}{c}\text { Participant } \\
\text { with } \\
\text { cancer }\end{array}$} & \multicolumn{2}{|c|}{$\begin{array}{l}\text { Diagnosed } \\
\text { cancer }\end{array}$} & \multirow{2}{*}{$\begin{array}{l}\text { Interval } \\
\text { cancer } \\
\text { - yield }\end{array}$} & \multirow{2}{*}{$\begin{array}{c}\text { Normal } \\
\text { participant }\end{array}$} & \multicolumn{4}{|c|}{ Image test (\%) } \\
\hline & & & & MRI & Mam & Total & & IC & DCIS & & & Sn & Sp & Sn & Sp \\
\hline 1 & Weinstein et al. ${ }^{21}$ & Prospective & 612 & 12 & 13 & 25 & 18 & 11 & 9 & - & 594 & 71 & 79 & 33 & 94 \\
\hline 2 & Lehman et al. ${ }^{22}$ & Prospective & 367 & 3 & 1 & 4 & 4 & 3 & 1 & - & 363 & 100 & - & 25 & - \\
\hline 3 & Leach et al. ${ }^{14}$ & Prospective & 649 & 27 & 14 & 35 & 20 & 27 & 6 & - & 629 & 77 & 81 & 40 & 93 \\
\hline 4 & Warner et al. ${ }^{12}$ & Prospective & 236 & 17 & 8 & 22 & 21 & 16 & 6 & 1 & 215 & 85 & 93 & 38 & 99.6 \\
\hline 5 & Kriege et al. ${ }^{23}$ & Prospective & 1909 & 32 & 18 & 45 & 50 & 4 & 6 & 4 & 1859 & 79.5 & 90 & 33 & 95 \\
\hline 6 & Kuhl et al. ${ }^{15}$ & Prospective & 529 & 39 & 14 & 43 & 41 & 34 & 9 & - & 488 & 91 & 97 & 33 & 97 \\
\hline 7 & Hagen et al. ${ }^{19}$ & Prospective & 491 & 18 & 10 & 25 & 25 & 16 & 3 & 5 & 466 & 86 & - & 50 & - \\
\hline
\end{tabular}


Table 7: Summary of the included study TP, FN, TP, TN, PPV, NPV, BRR, DY for MRI and Mammography

\begin{tabular}{|c|c|c|c|c|c|c|c|c|c|c|c|c|c|c|c|c|c|}
\hline \multirow{2}{*}{\multicolumn{2}{|c|}{ S/N Studies }} & \multicolumn{8}{|c|}{ MRI } & \multicolumn{8}{|c|}{ Mammography } \\
\hline & & FP & & TP & TN & PPV (\%) & NPV (\%) & BRR (\%) & DY $(\%)$ & FP & FN & TP & TN & PPV (\%) & NPV (\%) & BRR (\%) & DY (\%) \\
\hline 1 & Weinstein et al., (2009) & - & - & - & - & - & - & 25 & 1.1 & - & - & - & - & - & - & 29 & 2.1 \\
\hline 2 & Lehman et al., (2005) & 20 & - & - & - & 12.9 & - & 8.5 & 0.8 & 3 & - & - & - & 12.5 & - & 2.2 & 0.3 \\
\hline 3 & Leach et al., (2005) & - & - & - & - & 7.3 & 99 & - & - & - & - & - & - & 10 & 99 & - & - \\
\hline 4 & Warner et al., (2004) & 15 & 2 & 11 & 208 & 42 & 99 & - & - & 1 & 8 & 5 & 222 & 83 & 97 & - & - \\
\hline 5 & Kriege et al., (2004) & - & - & 167 & - & - & - & - & - & - & - & 112 & - & - & - & - & - \\
\hline 6 & Kuhl et al., (2005) & 39 & 4 & 39 & 1,370 & 50 & - & 78 & 16 & 45 & 29 & 14 & 1,364 & 23.7 & - & 59 & 40 \\
\hline 7 & Hagen et al., (2007) & - & - & - & - & - & - & - & - & - & - & - & - & - & - & - & - \\
\hline
\end{tabular}

in detecting DCIS compared to MRI. The reason for this could be as a result of the presence of micro-calcifications that is associated with DCIS, which can easily be detected by mammography. However four of these studies did not specify the actual number of DCIS detected by each of the various modalities as seen in the data extracted on Table 5. Only three of the studies gave values for the number of DCIS detected. ${ }^{15,22,23}$ Base on the few available data, the finding cannot be a conclusively one, which gives more room for further confirmation.

Furthermore, the diagnostic yield found for MRI and mammography was reported by three studies ${ }^{15,21,22}$ In these reports, it was noted that the diagnostic yield of mammography, was higher than that of MRI in two of the studies, ${ }^{15,21}$ where the percentages of the diagnostic yield for mammography was $40 \%$ and $2.1 \%$ Vs $16 \%$ and $1.1 \%$ for MRI, respectively. On the other hand, MRI was higher in Lehman et al..$^{22}$ report and was reported to be $0.8 \%$ vs $0.3 \%$ for mammography. There was no report in four of the other studies. ${ }^{1,14,19,23}$

Also, due to the rapidly progressive nature of some breast cancer associated with high risk population, some of the studies performed annual primary examination and also a follow up examinations on the study population. Table 5 holds a summary of the given follow up periods of each of the included studies, although no follow up report was given in Lehman et al. ${ }^{22}$ and a median follow up period of 0.5 years and 5.3 years was reported by Kuhl et al..$^{15}$ and Hagen et al. ${ }^{19}$ From the results of the follow ups, it was observed that MRI was still significantly more sensitive compared to mammography in the screening of asymptomatic women at high risk in the review population.

\section{CONCLUSION}

The evidence from this review demonstrate that MRI has a high sensitivity, and detected more breast cancer compared to that reported for mammography, in spite of its low specificity. Base on this evidence and in line with NICE guideline ${ }^{25}$, we suggests in our conclusion that, MRI should be used as the initial screening modality for asymptomatic women aged $18-45$ years at high risk of developing breast cancer in the absence of any contraindication and accessibility.

\section{LIMITATIONS STRENGTH}

This systematic review was undertaken as part of a Master of Science award at the University of Bradford. The review was initially done by AG under the supervision of BS. For publication purpose, the review process was repeated with independent evaluation by DM to ensure rigour of systematic review process.

One of the major limitations in this systematic review was observed during the data synthesis process. As a result of insufficient reports of some parameters required for a meta-analysis, only a descriptive synthesis was done for the review. Thus the review lacks homogeneity verification using statistical test of meta-analysis which could lead to some limitation in drawing the conclusion of the findings.

Also the review could suffer from publication bias, due to the fact that non-English language studies were excluded.

In the course of the review, it was however noted that some of the studies reviewed did not provide sufficient reports on some of the data's need to be extracted.

More so, most of the studies had a wide variation in the age range for their study population and some did not confine the study within the age range for this review, which could also be a possible source of bias.

\section{REFERENCES}

1. Alteri R and Bandi P. Breast cancer fact and figures 2011-2012 a publication of the American cancer society. [Online] Available from: http://www.cancer.org/acs/groups/content/@ epidemiologysurveilance/documents/document/acspc-030975. 
pdf [Accessed on $8^{\text {th }}$ August 2015]

2. Ferlay J, Soerjomataram I, Ervik M, Dikshit R, Eser S, Mathers C, et al. Cancer Incidence and Mortality Worldwide IARC Cancer Base. [online] Available from: http://globocan.iarc.fr [Accessed $6^{\text {th }}$ March 2015]

3. Claus EB, Risch N and Thompson WD. Autosomal dominant inheritance of early-onset breast cancer. Implication for risk prediction. Cancer 1994; 73(3): 643-651.

4. Ford D, Easton DF, Bishop DT, Narod SA and Goldgar DE. Risks of cancer in BRCA1-mutation carriers. Breast Cancer Linkage Consortium. Lancet 1994; 343(8899): 692-695.

5. Antoniou A, Pharoah PDP, Narod S, Risch HA, Eyfjord JE, Hopper JL, et al. Average risks of breast and ovarian cancer associated with BRCA1 or BRCA2 mutations detected in case series unselected for family history: a combined analysis of 22 studies, Am J Hum Genet 2003; 72(5): 1117-1130.

6. Serova OM, Mazoyer S, Puget N, Dubois V, Tonin P, Shugart YY, et al. Mutations in BRCA1 and BRCA2 in breast cancer families: are there more breast cancer-susceptibility genes? Am J Hum Genet 1997; 60(3): 486-495.

7. Easton DF, How many more breast cancer predisposition genes are there? Breast Cancer Research 1999; 1(1): 14-17.

8. American Cancer Society. Breast cancer prevention and early detection American cancer society 2014; 1.

9. Anders CK, Hsu DS, Broadwater G, Acharya CR, Foekens JA, Zhang $Y$, et al. Young age at diagnosis correlates with worse prognosis and defines a subset of breast cancers with shared patterns of gene expression. J Clin Oncol 2008; 26(20): 3324-3330.

10. Hussein A, Katia EK, Hafia D, Lana EK, Tarek HM and Nagi SE. Epidemiology and prognosis of breast cancer in young women. Journal of Thoracic Disease 2013; 5: 1.

11. Joann GE, Katrina A, Constance DL and Suzanne WF. Screening for Breast Cancer. JAMA 2005; 293(10): 1245-1256.

12. Warner E, Plewes DB, Hill KA, Causer PA, Zubovits JT, Jong RA, et al. Surveillance of BRCA1 and BRCA2 mutation carriers with magnetic resonance imaging, ultrasound, mammography, and clinical breast examination. JAMA 2004; 292(11): 1317-1325.

13. Kriege $M$, Brekelmans CTM, Obdeijn IM, Boetes $C$, Zonderland $\mathrm{HM}$ and Muller, SA. Factors affecting sensitivity and specificity of screening mammography and MRI in women with an inherited risk for breast cancer. Breast cancer Res Tret 2006; 100: $109-119$.

14. Leach MO, Boggis CR, Dixon AK, Easton DF, Eeles RA, Evans DG, et al. Screening with magnetic resonance imaging and mammography of a UK population at high familial risk of breast cancer: a prospective multicentre cohort study (MARIBS). Lancet 2005; 365(9473): 1769-1778.

15. Kuhl CK, Schrading S, Leutner CC, Morakkabati-Spitz N, Wardelmann E and Fimmers R. Mammography, breast ultrasound, and magnetic resonance imaging for surveillance of women at high familial risk for breast cancer. J Clin Oncol 2005; 23(33): 8469-8476.

16. Sardanelli $F$ and Podo F. Breast MR imaging in women at high risk of breast cancer. Is something changing in early breast cancer detection? Eur Radiol 2007; 17(4): 873-877.

17. Tilanus-Linthorst $M$, Verhoog $L$, Obdeijn IM, Bartels $K$, Menke-Pluymers $\mathrm{M}$ and Eggermont $\mathrm{A}$. A BRCA1/2 mutation, high breast density and prominent pushing margins of a tumour independently contribute to a frequent false-negative mammography. Int J Cancer 2002; 102: 91-95.

18. Bossuyt PM, Reitsma JB, Bruns DE, Gatsonis CA, Glasziou PP, Irwig LM, et al. The STARD Statement for Reporting Studies of Diagnostic Accuracy: Explanation and Elaboration. Clinical Chemistry 2003; 49(1): 7-18.

19. Hagen Al, Kvistad KA, Maehle L, Holmen MM, Aase H, Styr B, et al. Sensitivity of MRI versus conventional screening in the diagnosis of BRCA-associated breast cancer in a national prospective series. Breast 2007; 16(4): 367-374.

20. Lahmann PH, Friedenreich C, Schuit AJ, Salvini S, Allen NE, Key TJ, et al. Physical activity and breast cancer risk: the European Prospective Investigation into Cancer and Nutrition. Cancer Epidemiol Biomarkers Prev 2007; 16(1): 36-42.

21. Weinstein PS, Localio RA, Conant FE, Rosen M, Thomas MK and Schnall DM. Multimodality screening of high-risk women: A prospective cohort study. J Clin Oncol 2009; 27(36): 6124-6128.

22. Lehman $C D$, Blume JD, Weatherall $P$, Thickman $D$, Hylton $N$, Warner E, et al. Screening women at high risk for breast cancer with mammography and magnetic resonance imaging. Cancer 2005; 103(9): 1898-1905.

23. Kriege $M$, Brekelmans $C T$, Boetes $C$, Besnard PE, Zonderland HM, Obdeijn IM, et al. Efficacy of MRI and mammography for breast-cancer screening in women with a familial or genetic predisposition. N Engl J Med 2004; 351(5): 427-437.

24. Centre for Review and Dissemination (CRD). CRD's guidance for undertaking systematic reviews in healthcare. $2^{\text {nd }}$ ed. York: University of York; 2009.

25. NICE guideline 2013. Familial breast cancer: classification, care and managing breast cancer and related risks in people with a family history of breast cancer [Online] Available from: https:// www.nice.org.uk/guidance/cg164/chapter/1-recommendations [Accessed on 20 $0^{\text {th }}$ March 2016]

26. STARD checklist [Online] Available from: http://www.equatornetwork.org/reporting-guidelines/stard/[Accessed on $20^{\text {th }}$ March 2016]

27. Brown S, Hutton B, Clifford T, Doug C, Grima D, Wells G, et al. A Microsoft based tool for running and critically appraising network Meta-analysis-an overview and application of NetMetaXL. Syst.Rev 2014; 3(110). 